\title{
Analysis on the Effect of High Concentration Slug before Stopping Polymer Injection
}

\author{
Liqin Zhang \\ No.5 Oil Production Plant of Daqing Oilfield Company, Daqing, 163315, China \\ zhliqin@petrochina.com.cn
}

Keywords: Before Stopping Polymer Flooding, Plugging Slug, Molecular Weight

\begin{abstract}
With high concentration or high molecular weight with high concentration plugging slug can enhance recovery further, which make full use of high concentration polymer viscoelastic before stopping polymer flooding. These layers are usually well developed and connected, and has a certain pressure rise space. We optimized two blocks for polymer flooding in this block, the two blocks inject middle molecular weight with high concentration and high molecular weight with high concentration plugging slug respectively, we optimized the molecular weight, and find out that the 25 million plugging slug is better than the 7 million. The study has important guiding significance for late stage of polymer flooding.
\end{abstract}

\section{Introduction}

A industrial zone is the first industrial block in our factory, this block exploited horizon is PI3, which covers an area of $6.79 \mathrm{~km}^{2}$ and geological reserves is $634.38 \times 10^{4} \mathrm{t}$, underground pore volume is $1263.11 \times 10^{4} \mathrm{~m}^{3}$. The well spacing is $150 \mathrm{~m}$ apart with five-spot pattern, and the total number of Wells was 228, which including 101 injection Wells and 127 production Wells. The average thickness of a single well is $10.57 \mathrm{~m}$ and the net thickness is $8.27 \mathrm{~m}$. The block began polymer flooding in March 2009 and entered the water pick-up period in March 2013, this block water content ascend more than 95\% in 2015. The residual oil distributes very dispersedly at the stage, so has little potential for further exploitation [1].

According to the study of numerical simulation, injecting sealing plug before stopping polymer flooding can make the water fall further [2], and the production wells have a secondary effect, we optimized 3 and 4 blocks which wells develop and connect relatively good, the two blocks inject middle molecular weight with high concentration and high molecular weight with high concentration plugging slug respectively. From the experiment, the injection profile got obvious improvement and the water cut falls. By analysis of the effect of different Wells, we optimize the molecular weight, and find out that the 25 million plugging slug is better than the 7 million. It can be used as a reference for subsequent blocks.

\section{Parameter Optimization of Mathematical Model}

According to the analysis of the block, the plugging slug test before stopping polymer flooding was carried out in 3 and 4 blocks. The 3 fault block covers an area of $1.19 \mathrm{~km}^{2}$, and geological reserves is $119.13 \times 10^{4} \mathrm{t}$, and the pore volume is $237.40 \times 10^{4} \mathrm{~m}^{3}$. The number of Wells is 36 , which including 19 injection Wells and 17 production Wells. The average thickness of a single well is $10.9 \mathrm{~m}$ and the net thickness is $9.2 \mathrm{~m}$. The 4 fault block covers an area of $1.92 \mathrm{~km}^{2}$, and geological reserves is $231.93 \times 10^{4} \mathrm{t}$, and the pore volume is $461.17 \times 10^{4} \mathrm{~m}^{3}$. The number of Wells is 57 , which including 26 injection Wells and 31 production Wells. The average thickness of a single well is $13.6 \mathrm{~m}$ and the net thickness is $11.2 \mathrm{~m}$.

According to the study of numerical simulation [3], the molecular weight of block 3 and 4 block carried out optimization. The results shows that 3 block injecting 7 million is better than 25 million, and 4 block injecting 25 million is better than 7 million. So 3 block inject 7 million salt resistant 
polymer and 4 block inject 25 million polymer.

Table 1 Comparison of molecular weight optimization of 3 fault block

\begin{tabular}{|c|c|c|c|c|c|}
\hline \multirow[b]{2}{*}{$\begin{array}{l}\text { molecular } \\
\text { weight }\end{array}$} & \multicolumn{3}{|c|}{ stopping polymer flooding } & \multicolumn{2}{|c|}{ water cut $98 \%$} \\
\hline & water content (\%) & $\begin{array}{l}\text { stage of oil } \\
\text { production } \\
\left(10^{4} \mathrm{t}\right)\end{array}$ & water content (\%) & $\begin{array}{c}\text { stage of oil } \\
\text { production }\left(10^{4} \mathrm{t}\right)\end{array}$ & stage recovery (\%) \\
\hline water drive & & & & 2.32 & 1.97 \\
\hline 7 million & 93.47 & 13.03 & 10.94 & 18.53 & 15.56 \\
\hline 25 million & 93.50 & 12.84 & 10.77 & 18.31 & 15.37 \\
\hline
\end{tabular}

Table 2 Comparison of molecular weight optimization of 4 fault block

\begin{tabular}{|c|c|c|c|c|c|}
\hline \multirow{2}{*}{$\begin{array}{c}\text { molecular } \\
\text { weight }\end{array}$} & \multicolumn{2}{|c|}{ stopping polymer flooding } & \multicolumn{2}{c|}{ water cut 98\% } \\
\cline { 2 - 6 } & water content (\%) & $\begin{array}{c}\text { stage of oil } \\
\text { production } \\
\left(10^{4} \mathrm{t}\right)\end{array}$ & water content (\%) & $\begin{array}{c}\text { stage of oil } \\
\text { production (10 }\end{array}$ & stage recovery (\%) \\
\hline water drive & 94.58 & 26.81 & 11.56 & 3.57 & 1.54 \\
\hline 7 million & 94.54 & 26.93 & 11.61 & 34.33 & 14.75 \\
\hline 25 million & 9 & & & 14.80 \\
\hline
\end{tabular}

According to the study of numerical simulation, both 3 and 4 flocks have the best effect when they inject the concentration of polymer are $1600 \mathrm{mg} / \mathrm{L}$, so the concentration of $1600 \mathrm{mg} / \mathrm{L}$ is adopted in both zone[4] [5].

Table 3 Comparison of concentration optimization of 3 fault block

\begin{tabular}{|c|c|c|c|c|c|}
\hline \multirow[b]{2}{*}{$\begin{array}{l}\text { concentration } \\
\text { (mg/L) }\end{array}$} & \multicolumn{3}{|c|}{ at the end of injection } & \multicolumn{2}{|c|}{ water cut $98 \%$} \\
\hline & $\begin{array}{c}\text { water } \\
\text { content } \\
(\%)\end{array}$ & $\begin{array}{l}\text { stage of oil production } \\
\qquad\left(10^{4} t\right)\end{array}$ & $\begin{array}{c}\text { stage recovery } \\
\text { (\%) }\end{array}$ & $\begin{array}{c}\text { Stage of oil } \\
\text { production }\left(10^{4} \mathrm{t}\right)\end{array}$ & $\begin{array}{c}\text { stage recovery } \\
(\%)\end{array}$ \\
\hline water drive & & & & 2.32 & 1.97 \\
\hline 1200 & 93.55 & 12.93 & 10.85 & 18.42 & 15.46 \\
\hline 1600 & 93.47 & 12.98 & 10.90 & 18.52 & 15.54 \\
\hline 2000 & 93.52 & 12.96 & 10.88 & 18.46 & 15.49 \\
\hline
\end{tabular}

Table 4 Comparison of concentration optimization of 4 fault block

\begin{tabular}{|c|c|c|c|c|c|}
\hline \multirow[b]{2}{*}{$\begin{array}{c}\text { concentration } \\
(\mathrm{mg} / \mathrm{L})\end{array}$} & \multicolumn{3}{|c|}{ at the end of injection } & \multicolumn{2}{|c|}{ water cut $98 \%$} \\
\hline & $\begin{array}{c}\text { water } \\
\text { content } \\
(\%)\end{array}$ & $\begin{array}{l}\text { stage of oil production } \\
\qquad\left(10^{4} \mathrm{t}\right)\end{array}$ & $\begin{array}{c}\text { stage recovery } \\
\text { (\%) }\end{array}$ & $\begin{array}{l}\text { Stage of oil } \\
\text { production } \\
\left(10^{4} t\right)\end{array}$ & stage recovery (\%) \\
\hline water drive & & & & 3.57 & 1.54 \\
\hline 1200 & 94.57 & 26.75 & 11.53 & 34.12 & 14.71 \\
\hline 1600 & 94.54 & 26.93 & 11.61 & 34.33 & 14.80 \\
\hline 2000 & 94.54 & 26.84 & 11.57 & 34.24 & 14.76 \\
\hline
\end{tabular}

According to the study of numerical simulation [6], high concentration polymer slugs of $0.03 \mathrm{PV}$ is injected into both zone 3 and 4 .

\section{The Implementation of Plugging Slug}

Through the analysis of 3 block, with a total of 12 wells can inject 7 million plugging slug. These 12 Wells injected 7 million block slug in April 2015 with injection allocation of $450 \mathrm{~m}^{3}$ and concentration of $1537 \mathrm{mg} / \mathrm{L}$. It was stopped in May 2015 with 0.029 PV.

Through the analysis of 4 block, with a total of 15 wells can inject 25 million plugging slug. These 15 Wells injected 25 million block slug in May 2015 with injection allocation of $825 \mathrm{~m}^{3}$ and concentration of $1664 \mathrm{mg} / \mathrm{L}$. It was stopped in july 2015 with $0.03 \mathrm{PV}$. 
Table 5 The single well injection scheme of plugging slug with 7 million

\begin{tabular}{|c|c|c|c|c|c|c|c|}
\hline & fracture & & \multicolumn{3}{|c|}{ Before the plugging slug } & \multicolumn{2}{c|}{ million plugging slug } \\
\cline { 5 - 8 } Well No. & $\begin{array}{c}\text { pressure } \\
(\mathrm{MPa})\end{array}$ & $\begin{array}{c}\text { net thickness } \\
(\mathrm{m})\end{array}$ & $\begin{array}{c}\text { injection } \\
\text { pressure } \\
(\mathrm{MPa})\end{array}$ & $\begin{array}{c}\text { injection } \\
\text { allocation } \\
\left(\mathrm{m}^{3}\right)\end{array}$ & $\begin{array}{c}\text { injection } \\
\text { concentratio } \\
\mathrm{n}(\mathrm{mg} / \mathrm{L})\end{array}$ & $\begin{array}{c}\text { injection } \\
\text { allocation } \\
\left(\mathrm{m}^{3}\right)\end{array}$ & $\begin{array}{c}\text { injection } \\
\text { concentratio } \\
\mathrm{n}(\mathrm{mg} / \mathrm{L})\end{array}$ \\
\hline A1 & 13.9 & 9.5 & 12.8 & 80 & 1013 & 70 & 1800 \\
\hline A2 & 13.9 & 5.8 & 12.9 & 30 & 900 & 30 & 1300 \\
\hline A3 & 13.9 & 7.2 & 13.0 & 60 & 1200 & 60 & 1500 \\
\hline A4 & 14.0 & 8.2 & 8.0 & 40 & 975 & 40 & 1500 \\
\hline A5 & 14.1 & 8.8 & 9.8 & 60 & 600 & 50 & 1500 \\
\hline A6 & 13.9 & 12.2 & 12.8 & 20 & 600 & 20 & 1200 \\
\hline A7 & 14.0 & 7.8 & 13.4 & 25 & 840 & 25 & 1200 \\
\hline A8 & 14.0 & 10.1 & 12.8 & 20 & 600 & 20 & 1500 \\
\hline A9 & 14.0 & 7.3 & 13.5 & 35 & 771 & 35 & 1371 \\
\hline A10 & 13.9 & 12.4 & 13.4 & 30 & 600 & 30 & 1400 \\
\hline A11 & 14.0 & 4.5 & 13.5 & 20 & 600 & 20 & 1200 \\
\hline A12 & 14.0 & 6.8 & 13.3 & 60 & 1000 & 50 & 1800 \\
\hline combine & 14.0 & 8.4 & 12.4 & 480 & 869 & 450 & 1537 \\
\hline
\end{tabular}

Table 6 The single well injection scheme of plugging slug with 25 million

\begin{tabular}{|c|c|c|c|c|c|c|c|}
\hline \multirow[b]{2}{*}{ Well No. } & \multirow[b]{2}{*}{$\begin{array}{l}\text { fracture } \\
\text { pressure } \\
\text { (MPa) }\end{array}$} & \multirow[b]{2}{*}{$\begin{array}{c}\text { net } \\
\text { thickness } \\
(\mathrm{m})\end{array}$} & \multicolumn{3}{|c|}{ Before the adjustment } & \multicolumn{2}{|c|}{25 million plugging slug } \\
\hline & & & $\begin{array}{c}\text { injection } \\
\text { pressure } \\
\text { (MPa) }\end{array}$ & $\begin{array}{c}\text { injection } \\
\text { allocation } \\
\left(\mathrm{m}^{3}\right)\end{array}$ & $\begin{array}{c}\text { injection } \\
\text { concentration } \\
(\mathrm{mg} / \mathrm{L})\end{array}$ & $\begin{array}{c}\text { injection } \\
\text { allocation } \\
\left(\mathrm{m}^{3}\right)\end{array}$ & $\begin{array}{c}\text { injection } \\
\text { concentration } \\
(\mathrm{mg} / \mathrm{L})\end{array}$ \\
\hline B1 & 14.0 & 14.9 & 11.8 & 110 & 1173 & 60 & 2000 \\
\hline B2 & 14.0 & 13.6 & 13.5 & 70 & 814 & 60 & 1800 \\
\hline B3 & 13.9 & 17.6 & 10.2 & 90 & 1067 & 90 & 2000 \\
\hline B4 & 14.2 & 17.2 & 9.3 & 40 & 750 & 60 & 1800 \\
\hline B5 & 13.8 & 7.1 & 12.7 & 35 & 1457 & 35 & 1800 \\
\hline B6 & 14.0 & 13.3 & 12.7 & 70 & 1500 & 70 & 1971 \\
\hline B7 & 14.2 & 11.3 & 9.4 & 35 & 600 & 40 & 1500 \\
\hline B8 & 14.0 & 5.6 & 12.9 & 100 & 1050 & 100 & 1800 \\
\hline B9 & 14.0 & 4.1 & 13.2 & 30 & 600 & 30 & 1500 \\
\hline B10 & 13.7 & 10.5 & 13.2 & 40 & 750 & 40 & 1500 \\
\hline B11 & 13.9 & 10.0 & 12.8 & 20 & 600 & 20 & 1500 \\
\hline B12 & 14.2 & 10.9 & 12.2 & 40 & 750 & 40 & 1500 \\
\hline B13 & 14.2 & 5.2 & 9.4 & 115 & 1487 & 115 & 2009 \\
\hline B14 & 14.0 & 16.2 & 12.7 & 30 & 500 & 30 & 1500 \\
\hline B15 & 14.0 & 6.6 & 13.5 & 60 & 600 & 35 & 1286 \\
\hline combine & 14.0 & 10.9 & 12.0 & 885 & 913 & 1024 & 1664 \\
\hline
\end{tabular}

\section{Analysis on the Effect of Plugging Slug}

After injecting plugging slug, the injection profile improves dramatically. The fluid entry ratio of poor layer increased by 6.9 percentage points from $53.2 \%$ to $60.1 \%$ that injected 7 million, and relative suction increased by 7.2 percentage points from $29.3 \%$ to $36.5 \%$,at the same time,

the fluid entry ratio of good layer increased by 3.8 percentage points from $74.7 \%$ to $78.5 \%$, and relative suction decreased by 7.2 percentage points from $70.7 \%$ to $63.5 \%$.

The fluid entry ratio of poor layer increased by 9.8 percentage points from $51.1 \%$ to $60.9 \%$ that injected 25 million, and relative suction increased by 11.3 percentage points from $27.1 \%$ to $38.4 \%$, at the same time fluid entry ratio of good layer increased by 3.9 percentage points from $76.3 \%$ to $80.2 \%$, and relative suction decreased by 11.3 percentage points from $72.7 \%$ to $61.6 \%$.

The water content was from $95.1 \%$ to $93.6 \%$, which decreased $1.5 \%$ after injected 25 million plugging slug. Decrease amplitude was $0.7 \%$ above the 7 million plugging slug and was higher than 
no plugging slug wells beyond 2.2\%.

Table 7 Injection profile of plugging slug before and after with plugging slug

\begin{tabular}{|c|c|c|c|c|c|c|c|c|}
\hline \multicolumn{4}{|c|}{ Before and after 7 million plugging slug } & \multicolumn{3}{|c|}{ Before and after 25 million plugging slug } \\
\hline time & $\begin{array}{c}\text { fluid entry } \\
\text { ratio of } \\
\text { poor layer } \\
\text { (\%) }\end{array}$ & $\begin{array}{c}\text { fluid entry } \\
\text { ratio of } \\
\text { good layer } \\
(\%)\end{array}$ & $\begin{array}{c}\text { relative } \\
\text { suction } \\
\text { of poor } \\
\text { layer } \\
(\%)\end{array}$ & $\begin{array}{c}\text { relative } \\
\text { suction } \\
\text { of good } \\
\text { layer } \\
(\%)\end{array}$ & $\begin{array}{c}\text { fluid entry } \\
\text { ratio of } \\
\text { poor layer } \\
(\%)\end{array}$ & $\begin{array}{c}\text { fluid entry } \\
\text { ratio of } \\
\text { good layer } \\
(\%)\end{array}$ & $\begin{array}{c}\text { relative } \\
\text { suction } \\
\text { of poor } \\
\text { layer } \\
(\%)\end{array}$ & $\begin{array}{c}\text { relative } \\
\text { suction } \\
\text { of good } \\
\text { layer } \\
(\%)\end{array}$ \\
\hline $\begin{array}{c}\text { Before } \\
\text { plugging } \\
\text { slug }\end{array}$ & 53.2 & 74.7 & 29.3 & 70.7 & 51.1 & 76.3 & 27.1 & 72.7 \\
\hline $\begin{array}{c}\text { after } \\
\text { plugging } \\
\text { slug }\end{array}$ & 60.1 & 78.5 & 36.5 & 63.5 & 60.9 & 80.2 & 38.4 & 61.6 \\
\hline
\end{tabular}

Table 8 Classification of the maximum reduction of water content in plugging slug well area

\begin{tabular}{|c|c|c|c|c|c|c|}
\hline $\begin{array}{c}\text { Classification of } \\
\text { the maximum } \\
\text { reduction of water } \\
\text { content (\%) }\end{array}$ & $\begin{array}{c}\text { 7 million plugging slug } \\
\text { number }\end{array}$ & $\begin{array}{c}\text { Well number } \\
\text { ratio } \\
(\%)\end{array}$ & $\begin{array}{c}\text { maximum } \\
\text { reduction of water } \\
\text { content (\%) }\end{array}$ & well number & $\begin{array}{c}\text { Well number } \\
\text { ratio } \\
(\%)\end{array}$ & $\begin{array}{c}\text { maximum } \\
\text { reduction of } \\
\text { water content (\%) }\end{array}$ \\
\hline$<1$ & 6 & 40.0 & 0.2 & 4 & 20.0 & 0.3 \\
\hline $1-3$ & 5 & 33.3 & 1.3 & 5 & 25.0 & 1.4 \\
\hline $3-5$ & 3 & 20.0 & 3.5 & 7 & 35.0 & 3.5 \\
\hline$\geq 5$ & 1 & 6.7 & 5.1 & 4 & 20.0 & 6.6 \\
\hline combine & 15 & 100 & 1.5 & 20 & 100.0 & 3.0 \\
\hline
\end{tabular}

From the reduction of water content of single well, there were 11 wells which maximum reduction of water content exceed 3\%.It accounted for 55\% of the total number of oil wells, and was $28.3 \%$ higher than 7 million plugging slug.

According to the above statistics and analysis, it is believed that the effect of 25 million plugging slug is better than 7 million plugging slug. Therefore, it is recommended to use 25 million molecular weight polymers in the future plugging slug injection.

\section{Conclusion}

It can enhance recovery further, when inject high molecular weight and middle molecular weight with high concentration before stopping polymer flooding, it make full use of viscoelastic of polymer to displace the oil. The concentration should be higher than $1500 \mathrm{mg} / \mathrm{L}$ as far as possible within the range of acceptable pressure, these layers are usually well developed and connected, and has a certain pressure rise space.

\section{References}

[1] Zhai Yunfnag. Seepage Mechanics [M]. Petroleum Industry Press, 2009(7):13-23.

[2] Chen Taoping, Hu Jingbang. Petroleum Engineering [M]. Petroleum Industry Press, 2000(2): 376-393.

[3] Wang qimin, liao guangzhi, niu jingang. Practice and understanding of polymer flooding technology [J]. Daqing petroleum geology and development, 1999, 18(4):1-5.

[4] Wang xinhai, han dakuang, guo shangping. Polymer flooding mechanism and application [J]. Journal of petroleum science, 1994, 25(1):83-91.

[5] Cheng Jiecheng, Wang Demin. Optimization of molecular weight of polymer for oil displacement [J/OL] Journal of petroleum, 2000, (1).

[6] Yan Yaru Some understanding of polymer flooding test in the secondary reservoirs in the Sazhong Development Zone [J] Daqing Petroleum Geology and exploitation, 2004, 23 (4). 